\title{
Morphological distinction between estuarine polychaetes: Laeonereis culveri and L. nota (Phyllodocida: Nereididae)
}

\author{
Citlalli de Jesús-Flores ${ }^{1}$, S. Alejandro Salazar-González ${ }^{2,3} \&$ Sergio I. Salazar-Vallejo ${ }^{3 *}$ \\ 1. Universidad del Mar, Ciudad Universitaria, Puerto Ángel, Oaxaca, México; chikis-dejesus@hotmail.com \\ 2. Facultad de Ciencias Marinas, Universidad Autónoma de Baja California, Blvd. Costero 180, Ensenada, B.C., \\ México; seralesalgon@gmail.com \\ 3. El Colegio de la Frontera Sur, Depto. Sistemática y Ecología Acuática, Ave. Centenario km 5.5, Chetumal, Q. Roo, \\ México; ssalazar@ecosur.mx, savs551216@hotmail.com \\ * Correspondence
}

Received 16-III-2015. C Corrected 05-VIII-2015. Accepted 08-IX-2015.

\begin{abstract}
The family Nereididae includes more than 500 polychaete species described worldwide, and includes species common in many benthic environments, but some other species may tolerate freshwater or can even thrive in humid substrates in tropical forests. In estuarine environments, nereidid polychaetes can be abundant and relevant as a food source for resident or migratory birds. Laeonereis culveri (Webster, 1879) is a common estuarine species found in tropical and subtropical Atlantic American shores and was described from New Jersey; its median and posterior parapodia have upper notopodial ligules usually longer than the lower ones, and the latter are parallel to the notaciculae throughout the body. L. culveri distribution is from Connecticut to central Argentina; however, this wide distribution might be due to the inclusion of several other species as junior synonyms, despite that some morphological differences were found between them. One of such species is L. nota (Treadwell, 1941), that was described from Texas; its parapodia have notopodial ligules of about the same size, and the lower ones are oblique to the notaciculae. In order to clarify the differences between these two species, and to define which inhabits the Northwestern Caribbean region, topotype materials from these two species and specimens from Chetumal Bay were collected, and their morphological features were compared. Our results indicated that $L$. culveri and $L$. nota are different species and that the latter is found in Chetumal Bay. On the basis of mature specimens, L. culveri is hereby restricted to the Northern Gulf of Mexico and Northwestern Atlantic Ocean, and L. nota is reinstated and its distribution extends from Texas, in the Gulf of Mexico to Chetumal Bay, in the Northwestern Caribbean Sea. A key to identify all species in Laeonereis Hartman (1945) is also included. Rev. Biol. Trop. 64 (1): 189-201. Epub 2016 March 01.
\end{abstract}

Key words: taxonomy, Polychaeta, parapodial variations, Gulf of Mexico, Caribbean Sea, Annelida, shorebirds.

The polychaete family Nereididae de Blainville, 1818 includes species common in many benthic environments and has over 700 species in 45 genera worldwide (Read, 2015; Santos, Pleijel, Lana, \& Rouse, 2005) Because they have been known since Linneaus and are frequently included in invertebrate zoology texts, this family is probably one of the best known among the polychaetes. Some nereidid species occur in estuarine or freshwater environments (Glasby \& Timm, 2008), usually having more species than any other polychaete family in freshwater reservoirs (Foster, 1972); some species can even thrive in humid substrates in tropical forest trees (Glasby, Kitching, \& Ryan, 1990; Glasby, Mogi, \& Takahashi, 2003).

The morphological diagnostic features are well known for distinguishing genera among nereidids including prostomial, parapodial, chaetal and pharynx features, despite the fact that many undergo an impressive transformation of the body for reproduction (eyes become larger, and parapodia are transformed by a widening and enlargement of parapodial lobes 
and compound chaetal blades are replaced by wider, longer structures; a large part of their muscle bundles are reduced to release some room for gametes such that the body wall becomes transparent and delicate). This modification is known as epitoky and the morphological changes are so striking that after the first findings they were regarded and named as distinct genera. Among such taxa was Heteronereis Örsted, 1843 or Iphinereis Malmgren, 1866. It was through careful studies by Ehlers (1867) that they were shown as being reproductive stages of some already known genera. Reish (1957) indicated that epitoky is probably the most common method for reproduction among nereidids, but it is less common in estuarine or freshwater species (Herpin, 1925; Clark, 1961, 1977).

The delineation of Laeonereis (Hartman, 1945), has been problematic and the progress on it deserves explanation. Hartman (1945) proposed this new name as a replacement name for the junior homonym to solve the homonymy between Leptonereis Kinberg, 1866 and Leptonereis Claparède, 1870. She selected Nereis culveri Webster, 1879 as the type species for Laeonereis and based the generic diagnosis on the notochaetae being homogomph spinigers, the neurochaetae including homogomph spinigers and heterogomph falcigers, and papillae occurring on both pharynx rings. Pettibone (1971:14) noticed that there were some problems with the diagnosis and emended it to indicate that notopodial spingers and neuropodial falcigers and spinigers were all homogomph, and that multifid papillae (actually verticillate bars) were restricted to the maxillary or distal ring, with two triangular papillae only on the oral ring (area VI). This generic diagnosis was followed by Hartmann-Schröder (1977:144), and Fauchald (1977:87).

Laeonereis includes estuarine species, often abundant and usually living in muddy substrates with high organic matter content (González-Escalante, 2001; Hedgpeth, 1950). Members of the genus are usually a significant food source in shrimp ponds (de Paiva \& da Silva, 1998) or for migrating shore birds
(Weber \& Haig, 1997). In terms of karyotypic evolution, Laeonereis is also interesting because it has the largest number of chromosomes $(2 \mathrm{n}=38)$ (Ipucha, Santos, Lana, \& Sbalqueiro, 2007) among the nereidids.

There is another problem regarding the species included in Laeonereis, which are only known from tropical and subtropical American estuaries. Hartman (1938:14, 1945:21) felt that L. culveri (Webster, 1879), originally described from New Jersey, also included $L$. acuta (Treadwell, 1923) described from São Paulo, Brazil. Pettibone (1971:14) concluded that there was a single species, L. culveri distributed from North Carolina to Uruguay and in El Salvador along the Pacific coast, and this concept was followed in a key to Grand Caribbean species (Salazar-Vallejo \& Jiménez-Cueto, 1997). Pettibone (1971) followed Hartman $(1938,1945)$ and included as junior synonyms three other species: L. pandoensis (Monro, 1937) from a freshwater stream in Uruguay, L. nota (Treadwell, 1941) from an inner brackish water lagoon in Texas, and $L$. brunnea (Hartmann-Schröder, 1959) from estuaries in El Salvador. Further, Pettibone (1971) provided some illustrations for her specimens and showed some differences regarding the size and development of body features such as tentacular cirri, parapodia and pharynx.

Differences between supposed junior synonyms led previous authors to question such a large distribution. Orensanz and Gianuca (1974) concluded that there were morphological differences between L. culveri and L. acuta, and restricted their distribution with the former extending from North Carolina to the Gulf of Mexico, and the latter from Northern Brazil to the Valdés peninsula in Argentina. Pamplin, de Almeida and da Silva-Filho (2007) recorded L. acuta in Northern Brazil, and Liñero-Arana and Díaz-Díaz (2007) recorded it for the Southern Caribbean region. Likewise, L. brunnea was recently reinstated, and its distribution restricted to Pacific estuaries along Central America (Dean, 2001). A contrary perspective, based upon some morphological distortions due to preservation, led Oliveira, Santos, 
Lana and Camargo (2010) conclude that $L$. acuta is a junior synonym of $L$. culveri, but gave no details about a direct comparison of parapodial features.

Our objective was to assess which of the two North American Laeonereis species are present in Chetumal Bay by a comparison of their morphology and with topotype materials. The study of living specimens collected in Chetumal Bay, together with a comparison of preserved specimens from the same area and other specimens from Texas and North Carolina, revealed some interesting differences between them. In this contribution, important diagnostic differences are shown to distinguish two common estuarine species in tropical and subtopical Atlantic American shores: Laeonereis culveri (Webster, 1879), and L. nota (Treadwell, 1941), which is reinstated and can be found from Texas to the Northwestern Caribbean region, in estuarine areas. Topotype specimens are characterized and L. nota are reinstated. A key to identify all species in the genus is also included.

\section{MATERIALS AND METHODS}

Nereidid polychaetes were collected in Chetumal Bay, Quintana Roo, México, about $30 \mathrm{~m}$ from the shore at $1 \mathrm{~m}$ depth by shoveling fine sediment and sieving it through a 1 $\mathrm{mm}$ stainless steel mesh. Collecting trips were made, as detailed below, in April, 2011, July, 2012, September, 2013, and December 2014. Specimens were removed from the sieve with forceps and fixed in a $10 \%$ formaline solution or $95 \%$ ethanol. The formalin-fixed samples were later washed in tap water and preserved in $70 \%$ ethanol. All specimens were deposited in the Colección de Referencia, ECOSUR. Nontype specimens from Texas and North Carolina were collected before and studied during research visits to the National Museum of Natural History, Smithsonian Institution, Washington (USNM), and the Los Angeles County Museum of Natural History (LACM). Field data information was copied from labels but no other collecting or processing information was available. Other specimens from the Mexican state of Tamaulipas, deposited in the collections of the Laboratorio de Biosistemática, Facultad de Ciencias Biológicas collections (UANL) were also studied. Pharyngeal features were not emphasized because of the condition of specimens which were often soft and fragile, and since there were important diagnostic details in parapodial features. A series of digital photographs were made with a Canon PowerShot G6 camera, a microscope adapter PerspectiveImage, and later plates were prepared by combining some of these photos with HeliconFocus (http://www.heliconsoft.com) or by hand.

\section{RESULTS}

\section{Family Nereididae de Blainville, 1818 Laeonereis Hartman, 1945 \\ Laeonereis culveri (Webster, 1879)}

Fig. 1

Nereis culveri Webster, 1879:111-113, Pl. 3, Figs 23-30, Pl. 4, Figs 31-32.

Laeonereis culveri: Hartman, 1945:21 (partim); Hartman, 1951:44, Pl. 13, Figs 3-4 (partim); Pettibone (1971):14-19, Figs. 5-7 (partim); Gardiner, 1976:144, Fig. 13j-1.

Material examined from North Carolina: Two specimens (LACM n920), Fort Macon, North Carolina, vertical tubes, sand beach with water hole nearby, 16 Jun. 1940, O. Hartman, coll. Two specimens (USNM 53095), Oregon Inlet, muddy sand, intertidal, 17 Jun. 1973, S.L. Gardiner, coll. (body widest in median region; without posterior region, 53-70 $\mathrm{mm}$ long, $3 \mathrm{~mm}$ wide ( $2 \mathrm{~mm}$ w/o parapodia), 56-100 chaetigers). Five specimens (USNM 33292), Currituck Sound, 19 Oct. 1960, J.A. Kerwin, coll. (one complete, body widest in anterior region, $42 \mathrm{~mm}$ long, $2(1.5 \mathrm{~mm}$ w/o parapodia) $\mathrm{mm}$ wide, 133 chaetigers).

Characteristics: Body pale, progressively wider to median region (Fig. 1A). Prostomium wider than long; antennae tapered, as long as 

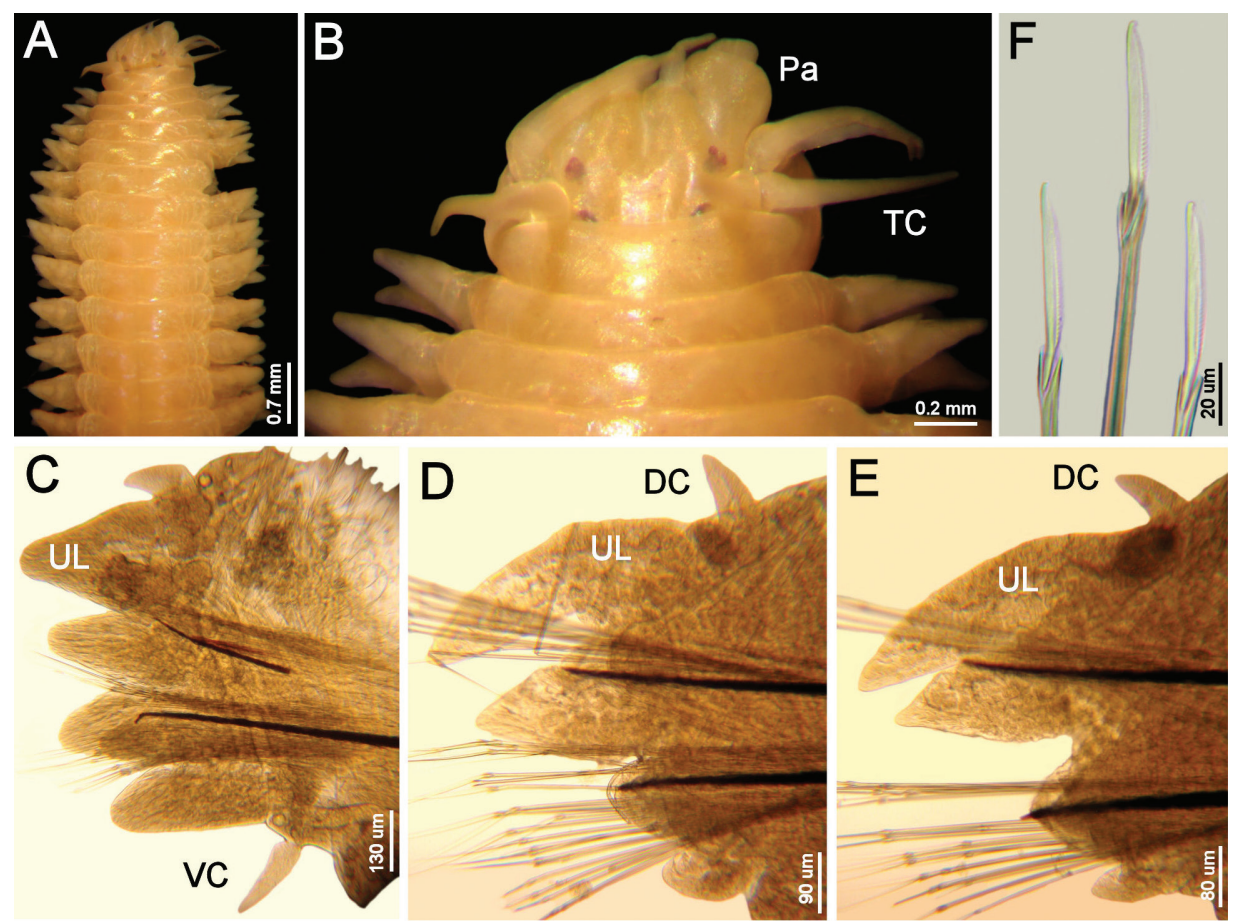

Fig. 1. Laeonereis culveri (Webster, 1879), mature male preserved before spawning (LACM n920). (A) Anterior region, dorsal view. (B) Anterior end, dorsal view. (C) Chaetiger 5, right parapodium, anterior view. (D) Chaetiger 30, right parapodium, anterior view. (E) Chaetiger 50, right parapodium, anterior view. (F) Same, tips of neuropodial falcigers (DC: dorsal cirrus, Pa: palp, TC: tentacular cirrus, UL: upper notopodial ligule, VC: ventral cirrus).

palps; eyes medium-sized (larger than basal antennal diameter), in a rectangle; anterior eyes reniform, posteriors oval. Peristomium wider than prostomium with 4 pairs of tentacular cirri, longest cirri reaching chaetiger 3 (Fig. 1B).

Anterior parapodia (Fig. 1C) slightly darker than those of median or posterior. Dorsal and ventral cirri subequal, tapered; dorsal cirri placed basally; basal glands large. Notopodial ligules asymmetrical, upper ligule blunt, triangular, lower ligule digitate.

Median and posterior parapodia modified (Fig. 1D and Fig. 1E). Upper notopodial ligule digitate, as long as, or longer than, lower notopodial ligule; lower ligule blunt, subtriangular, about twice as wide as upper notopodial ligule, parallel to notacicula. Dorsal and ventral cirri blunt; dorsal cirri larger than ventrals, placed basally; basal glands decreasing in size posteriorly (rarely of the same size or larger posteriorly); ventral cirri displaced ventrally, difficult to observe.

Neuropodial falcigers with blades 5-8 times longer than wide, finely denticulate, tip curved (Fig. 1F).

Reproduction: Webster (1879:113) noticed that his specimens were in good condition after $48 \mathrm{~h}$ in fresh-water. Further, he (Webster, 1879:113) indicated that eyes "become a little larger ... the body and feet are being swollen by the contained sexual products". No other modification of the relative size or shape of parapodial lobes was noticed. A better account, including parapodial ontogeny, dealing with apparently the same species was made by Mazurkiewicz (1975, 2009) who studied a population in Mystic River Estuary, Connecticut. Specimens were found living in rust-colored, mucous-lined burrows; adults 
were brown whereas sexually mature specimens were green (Mazurkiewicz, 1975:187). Spawning occurs within burrows and larvae were present in the sediment flocculent layer, never in the water column (Mazurkiewicz, 1975:197-198). Apparently larvae progressed to the 3-chaetiger stage and then left the maternal burrow while spent females remained alive for 10-16 days after spawning. Larval chaetae were slightly bent and denticles were larger than in adults. As for parapodial development, Mazurkiewicz (2009: Fig. 3) showed that the upper ligule was markedly longer than the lower one in a 19-chaetiger larvae and, because this is a diagnostic feature, these observations are regarded as being based upon a Northern population of L. culveri.

Remarks: Laeonereis culveri (Webster, 1879) differs from other species in the genus because it has elongated upper notopodial ligules in median and posterior chaetigers. This was clearly indicated in the original description (Webster, 1879) from New Jersey, and in other published accounts based upon North Carolinian materials (Gardiner, 1976:79).

Distribution: Originally described from Great Egg Harbor Bay (38 18'15" N $\left.74^{\circ} 38^{\prime} 59^{\prime \prime} \mathrm{W}\right)$, New Jersey, it has been found from Connecticut to Florida, and in the Gulf of Mexico, after Pettibone (1971: Fig. 7), it has recorded from Georgia, in estuarine environments especially in intertidal to shallow subtidal muddy substrates.

\section{Laeonereis nota (Treadwell, 1941)}

Fig. 2, Fig. 3 and Fig. 4

Leptonereis nota Treadwell, 1941:1-3, Figs 7-10.

Laeonereis culveri: Hartman, 1951:44, Pl. 13, Figs 3-4 (partim, non Webster, 1879); Pettibone (1971):14-19, Figs 5-7 (partim, non Webster, 1879); de León-González, 1997:7476, Figs 38-39 (non Webster, 1879); de León-González, 2009:330, Fig. 3A-D (non Webster, 1879).
Laeonereis acuta: Liñero-Arana \& DíazDíaz, 2007:154-157, Fig. 2 (non Treadwell, 1923).

Material examined from Texas: Three specimens (LACM n 4968) Aransas Wildlife Refuge, 21 Feb. 1946, J.W. Hedgpeth, coll. (atokes; two complete: $36-45 \mathrm{~mm}$ long, 1.3-1.4 mm wide (chaetiger 6), 99-105 chaetigers). Five specimens (LACM n 4979), Aransas Refuge, near Rockport, Texas, 13 Feb. 1947, J.W. Hedgpeth, coll. Three mature specimens (LACM n 6375), inside jetty, Institute of Marine Science, 21 Oct. 1950, A.E. Hartman, coll. One specimen (USNM 43401), upper part of Galveston Bay, center of Trinity Bay, mud, 18 Dec. 1969, G.E. Williams, coll. (body wider in anterior region; $56 \mathrm{~mm}$ long, 2.5 (1.5 w/o parapodia) $\mathrm{mm}$ wide, 120 chaetigers). Tamaulipas: 24 specimens (UANL 3889), none complete, Matamoros, intertidal, Apr. 1982, G. Góngora-Garza, coll. Chetumal Bay: Ca. 100 specimens (ECOSUR 2819), Nieves, $1 \mathrm{~m}$, mud, 1 Apr. 2011, L.F. Carrera \& SISV, coll. Three specimens (ECOSUR 2820), Nieves, 1 m, mud, 10 Jul. 2012, SASG \& SISV, coll. 50 specimens (ECOSUR 2821), Nieves, $1 \mathrm{~m}$, mud, 6 Sep. 2013, CDJF \& SISV, coll. 29 specimens (ECOSUR 2825), Arenal Norteño, $0.1 \mathrm{~m}$, mud, 29 Dec. 2014, V. Conde, coll.

Texas male: Body pale, slightly wider by chaetigers 5-7, tapered posteriorly (Fig. 2A). Prostomium as long as wide; antennae tapered, slightly shorter than palps; eyes medium-sized (larger than basal antennal diameter), in a rectangle; anterior and posterior eyes reniform, posteriors directed laterally, look longer than wide. Peristomium wider than prostomium with 4 pairs of tentacular cirri, longest cirri reaching chaetiger 2 (Fig. 2B).

Anterior parapodia (Fig. 2C) slightly darker than those of median or posterior. Dorsal and ventral cirri subequal, tapered; dorsal cirri placed basally; basal glands large. Notopodial ligules asymmetrical, upper ligule blunt, triangular, lower ligule digitate. 

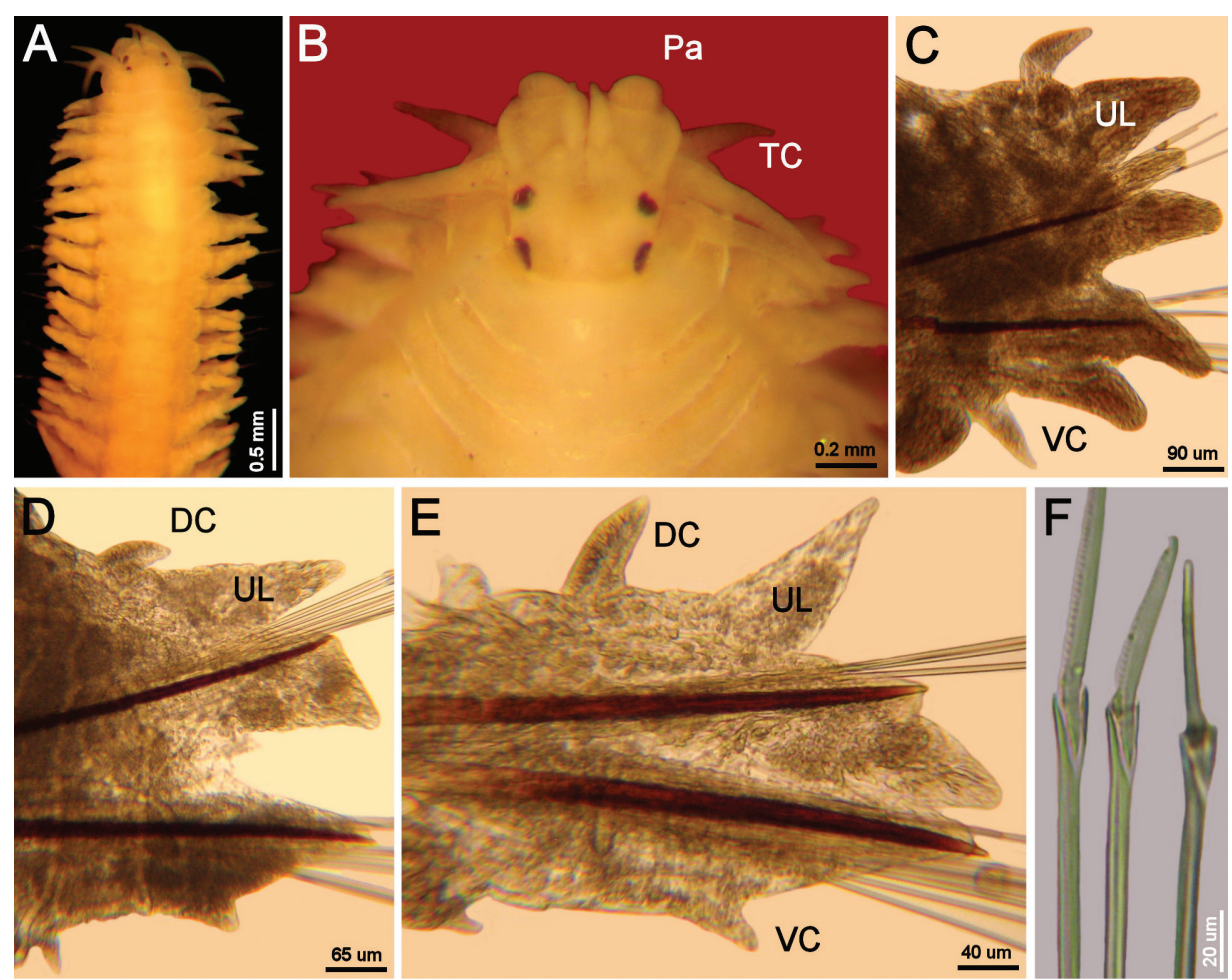

Fig. 2. Texas. Laeonereis nota (Treadwell, 1941), mature male (LACM n6375). (A). Anterior region, dorsal view. (B). Anterior end, dorsal view. (C). Chaetiger 5, right parapodium, posterior view. (D). Chaetiger 29, right parapodium, posterior view. (E) Chaetiger 50, right parapodium, posterior view. (F) Same, lower neurochaetae, falcigers in lateral and frontal views (DC: dorsal cirrus, Pa: palp, TC: tentacular cirrus, UL: upper notopodial ligule, VC: ventral cirrus).

Median and posterior parapodia slightly modified (Fig. 2D and Fig. 2E). Upper notopodial ligule triangular, blunt, shorter or about as long as lower notopodial ligule; lower ligule blunt, subtriangular, about twice as wide as upper notopodial ligule, oblique to notacicula. Dorsal and ventral cirri blunt; dorsal cirri larger than ventral ones, placed basally; basal glands decreasing in size and less pigmented posteriorly. Ventral cirri displaced ventrally, difficult to observe.

Neuropodial falcigers with blades 5-8 times longer than wide, finely denticulate, tip curved (Fig. 2F). Sperm plaques visible in median and posterior segments. Another specimen without posterior end had some sperm masses close to neuropodia in a few posterior chaetigers.

Texas female: Body pale, wider by chaetigers 5-7, tapered posteriorly. Prostomium as long as wide; antennae tapered, as long as palps; eyes medium-sized (larger than basal antennal diameter), in a rectangle; anterior and posterior eyes reniform, posteriors directed laterally, slightly longer than wide. Peristomium wider than prostomium with 4 pairs of tentacular cirri, longest cirri reaching chaetiger 3 (Fig. 3A).

Anterior parapodia (Fig. 3B) slightly darker than those of median or posteriors, full of oocytes. Dorsal and ventral cirri subequal, tapered; dorsal cirri placed basally; basal glands large. Notopodial ligules asymmetrical, upper ligule slightly wider than lower one.

Median and posterior parapodia slightly modified (Fig. 3C and Fig. 3D). Upper notopodial ligule triangular, blunt, as long as lower notopodial ligule; lower ligule blunt, subtriangular, as wide as upper notopodial ligule, oblique to notacicula. Dorsal and ventral cirri 

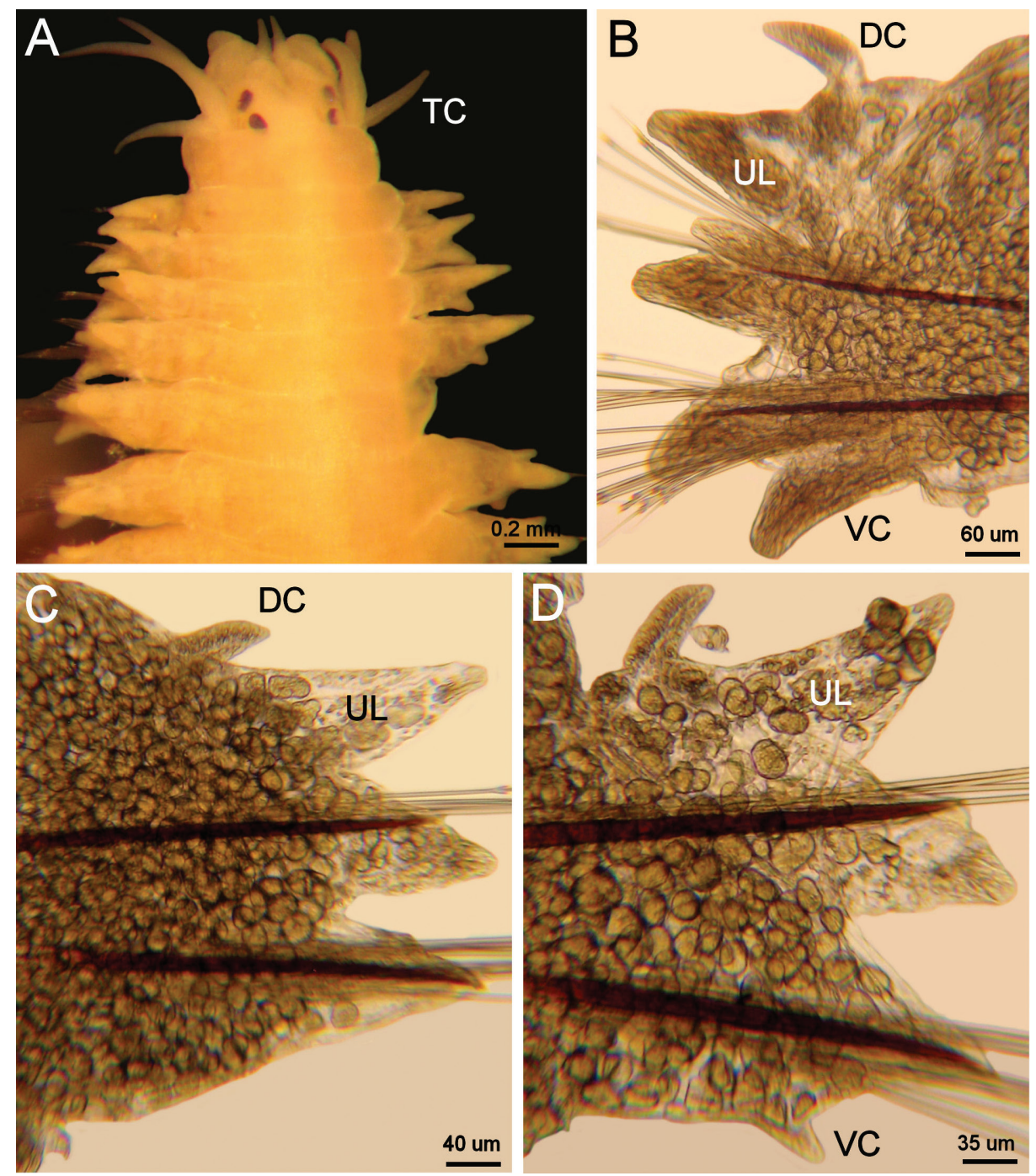

Fig. 3. Laeonereis nota (Treadwell, 1941), mature female (LACM n6375), preserved before spawning. (A) Anterior end, dorsal view. (B) Chaetiger 5, right parapodium, anterior view, ventral cirri collapsed. (C) Chaetiger 30, right parapodium, posterior view. (D) Chaetiger 50, right parapodium, posterior view (DC: dorsal cirrus, TC: tentacular cirrus, UL: upper notopodial ligule, $\mathrm{VC}$ : ventral cirrus).

blunt; dorsal cirri larger than ventral ones, placed basally; basal glands markedly decreasing in size and less pigmented posteriorly. Ventral cirri displaced ventrally, difficult to observe. Immature oocytes 50-80 $\mu \mathrm{m}$ in diameter.

Chetumal Bay: Body pale, up to $38 \mathrm{~mm}$ long, $2.8 \mathrm{~mm}$ wide, 115 chaetigers. Prostomium with an anterior furrow, small, pigmented glands in juveniles (Fig. 4A); antennae thin, as long as palps. Eyes black, in a rectangle; anterior eyes reniform, posteriors oval in adults (Fig. 4D). Palps biarticulated, palpostyle rounded. Peristomium slightly longer than first chaetiger, with 4 pairs of tentacular cirri, longest pair reaching chaetiger 2 in adults, or chaetiger 3 in juveniles.

Anterior parapodia with 3 notopodial ligules, blunt, upper and lower subtriangular, median smaller, digitate (Fig. 4B, Fig. 4E). 

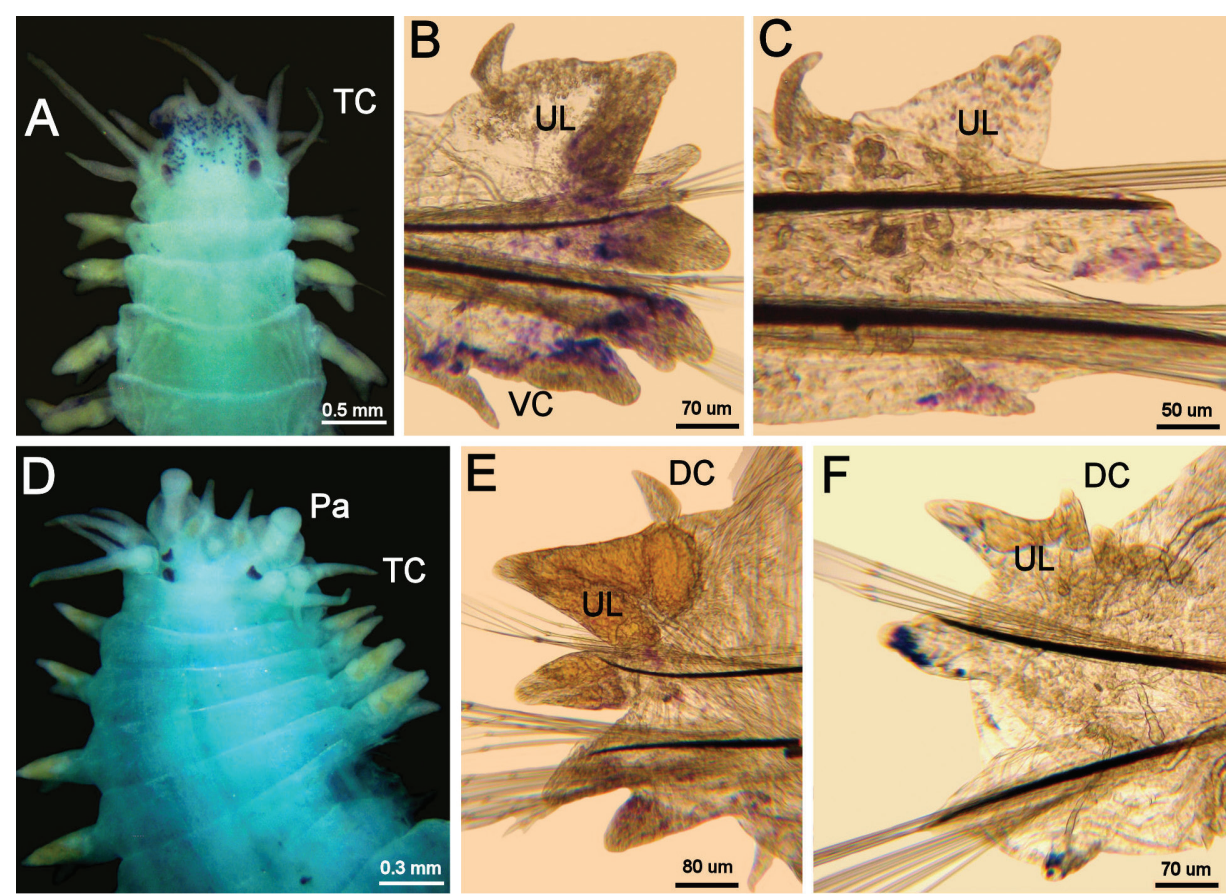

Fig. 4. Laeonereis nota (Treadwell, 1941). Specimens temporarily stained with methyl-green. (A) Juvenile (ECOSUR 2820), fixed in formalin, anterior end, dorsal view. (B) Chaetiger 5, right parapodium, posterior view. (C) Chaetiger 30, right parapodium, posterior view. (D) Adult specimen (ECOSUR 2821), fixed in ethanol, anterior end, dorsal view. (E) Chaetiger 5, left parapodium, posterior view. (F) Chaetiger 30, left parapodium, posterior view (DC: dorsal cirrus, Pa: palp, TC: tentacular cirrus, UL: upper notopodial ligule, VC: ventral cirrus).

Dorsal and ventral cirri subequal; dorsal cirri basally inserted, small, often incurved; ventral cirri digitate, larger than those present on posterior chaetigers.

Median and posterior parapodia slightly modified (Fig. 4C, Fig 4F). Upper notopodial ligule triangular, blunt, as long as lower notopodial ligule; lower ligule blunt, subtriangular, as wide as upper notopodial ligule, oblique to notacicula. Dorsal and ventral cirri blunt; dorsal cirri larger than ventral ones, placed basally; basal glands markedly decreasing in size and less pigmented posteriorly. Ventral cirri displaced ventrally, difficult to observe. Sex ratio and oocytes: from 25 adult specimens, 18 were females, 7 were males. Mature oocytes 130$150 \mu \mathrm{m}$ in diameter (largest ones, in December specimens up to $200 \mu \mathrm{m})$.

Reproduction: Klesch (1970) studied a population in Harbor Island, Redfish Bay,
Texas and noted that immature adults were redorange, while sexually mature specimens were greenish, with adult males being light green to yellow and females deeper olive green. Mature specimens undergo widespread tissue histolysis including a great reduction of body wall musculature, septa and the intestinal tract. Klesch (1970:77) indicated that mature specimens spawn inside their burrows and that larvae were found within the burrows; spawned specimens usually die within the next $24 \mathrm{~h}$.

Remarks: Laeonereis nota (Treadwell, 1941) resembles L. acuta (Treadwell, 1923) as shown in the key below, and both differ from $L$. culveri (Webster, 1879) since the latter has very long upper notopodial ligules in median and posterior chaetigers. There are several differences between $L$. nota and L. acuta, however. In $L$. nota the longest tentacular cirri reach chaetigers 2-3, and its dorsal cirri are half as 
long as upper notopodial ligule, whereas in $L$. acuta the longest tentacular cirri reach chaetiger 5, and its dorsal cirri are one-third as long as upper notopodial ligule.

The specimens from Chetumal Bay are mostly soft bodied, probably collected after spawning, and this would explain their condition; however, because of their morphological features, they are regarded as conspecific with L. nota. The original description indicated that the holotype, and unique specimen, was blackish; however, no other topotype specimen shows dark pigmentation, and those from Chetumal are pale when alive as well. Specimens that are pale when preserved can take a dark pigmentation if they become partly dehydrated, if there was a black rubber sealer whose pigment often leaks into the fluid, or if China ink-labels were introduced before ink dried out into the jars. In some instances, this artificial pigmentation can be removed after surface brushing, and this could explain why we regard holotype pigmentation as a preservation artifact; further, no topotype specimen had any pigmentation remains.

Distribution: Originally described from Offats Bayou, Galveston (29¹6’52" N 9449'33" W), Texas, it was recorded for the Mexican states of Tamaulipas, Veracruz and Campeche (de León-González, 1997), and this study extends it distribution into Chetumal Bay, in the Northwestern Caribbean Sea, in estuarine areas in intertidal or shallow subtidal muddy substrates. Other records for this species from Venezuela, under L. acuta, extend this distribution along the Southern Caribbean as well.

\section{Key to species of Laeonereis Hartman, 1945}

(after Read \& Glasby 2015; preserved specimens)

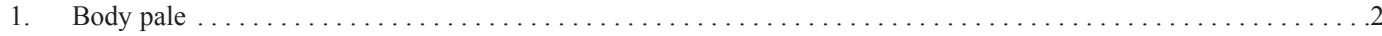

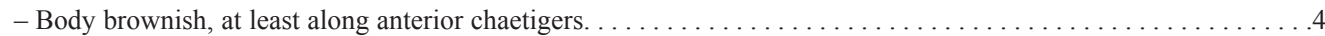

2(1). Median chaetigers with notopodial ligules of about the same size; mandibles with 12 teeth. ............ - Median and posterior chaetigers with upper notopodial ligule longer than lower one; mandibles with up to 14 teeth; longest tentacular cirri reach chaetigers $2-3 \ldots \ldots \ldots \ldots \ldots \ldots \ldots \ldots \ldots \ldots \ldots \ldots \ldots$. . W . Webster, 1879)

3(2). Longest tentacular cirri reach chaetigers 2-3; dorsal cirri half as long as upper notopodial ligule

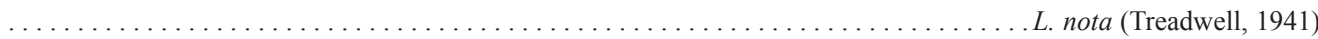

- Longest tentacular cirri reach chaetiger 5; dorsal cirri one-third as long as upper notopodial ligule

............................. acuta (Treadwell, 1923) (ant. end illustr. Omena \& Amaral, 2001)

4(1). Pygidium pale; dorsal cirri as long as upper notopodial ligule; several homogomph neuropodial falcigers from chaetiger 15, blades 5-6 times longer than wide . . . . . . . . L. brunnea Hartmann-Schröder, 1959 (redescr. Dean, 2001) - Pygidium with a pigmented rim; dorsal cirri 1/3-1/4 as long as upper notopodial ligules; several homogomph neuropodial falcigers from chaetiger 12 (20 fide Orensanz \& Estivariz, 1971), blades more than 10 times longer than wide L. pandoensis (Monro, 1937) (redescr. Orensanz \& Estivariz, 1971)

\section{DISCUSSION}

The generic diagnostic features of nereidid polychaetes are rather conservative as there are usually two biarticulate palps, two antennae, usually four pairs of tentacular cirri and four eyes, and parapodia are usually biramous (Fauchald, 1977). There are a few genera with distinct modifications along the body such as branchiae (Dendronereis, Dendronereides), elytrae-shaped dorsal cirri (Kainonereis), or enlarged dorsal cirri in posterior parapodia (Alitta). Similar genera are usually separated upon some features of their pharynx armature or on the type of chaetae. Along the body of most adult, non-epitoke nereidids the parapodia 
change along one of two patterns, especially along median and posterior parapodia: they are either progressively smaller or become enlarged posteriorly. Laeonereis Hartman, 1945 is a well-delineated genus because its species do not undergo epitoky, have parapodia progressively smaller along the body, their pharynx has soft papillae and tufts of verticillate papillae, and compound homogomph falcigers in posterior parapodia.

Pettibone (1971) disregarded the differences in parapodial features between the type species, L. culveri, and the other described ones. This was probably because it was known that nereidids undergoing epitoky show drastic transformations in their body, including parapodial features. However, it is now known that no species of Laeonereis displays epitoky and differences in parapodial morphology are here shown instead to be taxonomically significant, allowing species to be distinguished. Further, even eye size is not so markedly modified, and consequently the former inclusion of all species-name groups under the type species must be rejected.

Mazurkiewicz (1975) found that early development occurs within Laeonereis burrows or tubes, and that their larvae live in the flocculent layer, not in the water column; this implies a low dispersal potential. If this type of larval development and behavior are widespread among Laeonereis species, they would have a very small dispersal potential, and their wide geographic distribution, even restricted to those ranges indicated above, would be difficult to explain. The answer may lie in migratory birds. Weber and Haig (1997) found that in two shorebird species (Charadriiformes), jaws of $L$. culveri were the main food item and that ingested worm size was related to birds' peak length. If this type of predation is size-dependent, probably birds could passively disperse smaller specimens or larvae within the sediment taken on feet and plumage. If there were only two species involved, they might seem too little for this distributional range, but there are more shorebird species in the region. For example, in Texas and close to the type locality of L. nota, Withers and Chapman (1993) counted 35000 shorebirds of 26 species, and not surprisingly, the former author (Withers, 2002) found that they were especially abundant in Texas and Florida's SW coast in the United States, and in Laguna de Términos and Progreso, in the Yucatan Peninsula, Mexico. This type of dispersal is well documented among freshwater invertebrates (Bilton, Freeland, \& Okamura, 2001; Frisch, Green, \& Figuerola, 2007) in comparison to marine invertebrates, but because it seems to be also effective for those groups lacking dormant or diapause adaptations, it renders attractive for future research in marine environments. A recent paper by Simonis and Ellis (2014) has shown that bathing gulls can passively disperse rock-pool invertebrates, such that passive dispersal would include those birds not directly feeding on polychaetes as well.

Nevertheless, despite the fact that estuaries are very variable and stressful due to their daily and seasonal changes in salinity, temperature and organic matter content, there must be some restraints on cosmopolitan distribution of estuarine species. Distributional patterns must follow a set of limitations within the ecological horizon for each species (SalazarVallejo, Carrera-Parra, González, \& SalazarGonzález, 2014) and defining distributional ranges or their limits is especially difficult in a progressively warming world, but worthy of further pursuit.

\section{ACKNOWLEDGMENTS}

Citlalli and Alejandro made summer research stays in Ecosur-Chetumal, and they wholeheartedly thank Emilia González-Vallejo for housing and feeding them. Funding for this research, including the visits to the museums of Los Angeles and in Washington was provided by ECOSUR. Sergio thanks the continued support by Leslie Harris and Dave Ocker (LACM), and Katie Ahlfeld, Geoff Keel, Linda Ward, Kristian Fauchald, and Karen Osborn (USNM). Cinthya Santos let us study some specimens of Laenoereis pandoensis from Brazil. J. Ángel de 
León-González and Víctor M. Conde-Vela read an earlier draft. However, the careful reading by four referees and by Daisy Arroyo resulted in a much improved document.

\section{RESUMEN}

Distinción morfológica de dos poliquetos neréididos estuarinos: Laeonereis culveri (Webster, 1879) y L. nota (Treadwell, 1941). La familia Nereididae incluye especies comunes y frecuentes en muchos ambientes bénticos y cuenta con más de 500 especies en todo el mundo, y algunas pueden tolerar ambientes dulceacuícolas e incluso viven en sustratos húmedos en bosques tropicales. Como ocurre en otras especies estuarinas, los poliquetos neréididos pueden ser abundantes y relevantes como fuente de alimento para aves residentes o migratorias. Laeonereis culveri (Webster, 1879) es una especie común en estuarios, fue descrita de Nueva Jersey, E.U.A.; sus parápodos medianos y posteriores tienen lígulas notopodiales superiores generalmente más largas que las inferiores, y estas últimas son paralelas a las notacículas a lo largo del cuerpo. La distribución de L. culveri comprende desde Connecticut, E.U.A. hasta el litoral central de Argentina; esta amplia distribución podría deberse a la inclusión de otras especies como sinónimos menores, a pesar de las diferencias morfológicas entre ellas. Una de dichas especies, L. nota (Treadwell, 1941) fue descrita de Texas; sus parápodos medios y posteriores tienen lígulas notopodiales superiores de longitud similar a las inferiores, y estas últimas son oblicuas a las notacículas. Para clarificar las diferencias entre estas dos especies y determinar cuál de ellas se encuentra en el Caribe noroccidental, se estudiaron topotipos de ambas especies y se recolectaron ejemplares de la Bahía de Chetumal para comparar sus atributos morfológicos. Nuestros resultados indican que $L$. culveri y L. nota son especies diferentes y que la última se presenta en la Bahía de Chetumal. Con base en ejemplares maduros, L. culveri se restringe al norte del Golfo de México y Atlántico noroccidental y $L$. nota se reestablece con una distribución que se extiende desde Texas, en el Golfo de México a la Bahía de Chetumal, en el Caribe noroccidental. También se incluye una clave para la identificación de todas las especies de Laeonereis Hartman, 1945.

Palabras clave: taxonomía, Polychaeta, variaciones parapodiales, Golfo de México, Mar Caribe, Annelida, aves costeras.

\section{REFERENCES}

Bilton, D. T., Freeland, J. R., \& Okamura, B. (2001). Dispersal in freshwater invertebrates. Annual Review of Ecology and Systematics, 32, 159-181.
Clark, R. B. (1961). The origin and formation of the heteronereis. Biological Reviews, 36, 199-236.

Clark, R. B. (1977). Reproduction, speciation and polychaete taxonomy. In D. J. Reish, \& K. Fauchald (Eds.), Essays on the Polychaetous Annelids in Memory of Dr Olga Hartman (pp. 477-502). California: Allan Hancock Found, University of Southern California.

De León-González, J. A. (1997). Nereidos (Polychaeta: Nereididae) de los litorales mexicanos: Sistemática, Biogeografía y Alimentación (Tesis Doctoral). Universidad Autónoma de Nuevo León, Monterrey.

De León-González, J. A. (2009). Nereididae Lamarck, 1818. In J.A. De León-González, J. R. BastidaZavala, L. F. Carrera-Parra, M. E. García-Garza, A. Peña-Rivera, S. I. Salazar-Vallejo, \& V. Solís-Weiss (Eds.), Poliquetos (Annelida: Polychaeta) de México y América Tropical (pp 325-354). Monterrey, México: Universidad Autónoma de Nuevo León.

De Paiva, P. C., \& da Silva, R. M. C. (1998). Macrobenthic invertebrates as food for penaeid shrimp pond farms in Brazil. Revista de Biología Tropical, 46, 427-430.

Dean, H. K. (2001). Some Nereididae (Annelida: Polychaeta) from the Pacific coast of Costa Rica. [Suplemento 2]. Revista de Biología Tropical, 49, 37-67.

Ehlers, E. (1867). Die Gattungen Heteronereis (Oerd) und ihr Verhältniss zu den Gattungen Nereis (Gr) und Nereilepas (Gr). Nachrichten von der Königl. Gesellschaft der Wissenschaften und der GeorgAugusts-Universität zu Göttingen, 1867, 209-217.

Fauchald, K. (1977). The Polychaete Worms: Definitions and Keys to the Orders, Families and Genera. California: Natural History Museum of Los Angeles County.

Foster, N. (1972). Freshwater polychaetes (Annelida) of North America. Environmental Protection Agency, Biota of Freshwater Ecosystems Identification Manual. Washington,U.S.: Environmental Protection Agency.

Frisch, D., Green, A. J., \& Figuerola, J. (2007). High dispersal capacity of a broad spectrum of aquati invertebrates via waterbirds. Aquatic Sciences, 69, 568-574.

Gardiner, S. L. (1976). Errant polychaete annelids from North Carolina. Journal of the Elisha Mitchell Scientific Society, 91, 77-220.

Glasby, C. J., Kitching, R. L., \& Ryan, P. A. (1990). Taxonomy of the arboreal polychaete Lycastopsis catarractarum Feuerborn (Namanereidinae: Nereididae), with a discussion of the feeding biology of the species. Journal of Natural History, 24, 341-350.

Glasby, C. J., Mogi, M., \& Takahashi, K. I. (2003). Occurrence of the polychaete Namalycasits hawaiiensis Johnson, 1903 (Nereididae: Namanereidinae) in Pandanus leaf axils on Palau, West Pacific. Beagle, 
Records of the Museums and Art Galleries of the Northern Territory, 19, 97-99.

Glasby, C. J., \& Timm, T. (2008). Global diversity of polychaetes (Polychaeta: Annelida) in freshwater. Hydrobiologia, 595, 107-155.

González-Escalante, L. E. (2001). Evaluación de los poliquetos neréididos Nereis sp. y Laeonereis culveri (Webster, 1879), como bioindicadores del contenido de materia orgánica en la bahía de Chetumal, Q. Roo (Tesis Profesional). Instituto Tecnológico Chetumal. México.

Hartman, O. (1938). Nomenclatorial changes involving types of polychaetous annelids of the family Nereidae in the United States National Museum. Journal of the Washington Academy of Sciences, 28, 13-15.

Hartman, O. (1945). The marine annelids of North Carolina. Duke University Marine Station, Bulletin, 2, 1-51.

Hartman, O. (1951). The littoral marine annelids of the Gulf of Mexico. Publications of the Institute of Marine Science, University of Texas, 2, 7-124.

Hartmann-Schröder, G. (1959). Zur Ökologie der Polychaeten des Mangrove-Estero-Gabietes von El Salvador. Beiträge zur Neotropische Fauna, 1, 69-183.

Hartmann-Schröder, G. (1977). The Genera Ceratocephale Malmgren, Olganereis n.gen., and Profundilycastis n. gen. (Polychaeta) with a key to the nereid genera without chitinous paragnaths. In D. J. Reish, \& K. Fauchald (Eds.), Essays on the Polychaetous Annelids in Memory of Dr Olga Hartman (pp. 141-156). California: Allan Hancock Found, University of Southern California.

Hedgpeth, J. W. (1950). Notes on the marine invertebrate fauna of salt flat areas in Aransas National Wildlife Refuge, Texas. Publications of the Institute of Marine Science, University of Texas, 1, 103-119.

Herpin, R. (1925). Recherches biologiqus sur la reproduction et le développement des quelques annélides polychètes. Bulletin de la Société des Sciences Naturelles de l'Ouest de la France, Séries 4ème, 5, 1-250.

Ipucha, M. C., Santos, C. G., Lana, P. C., \& Sbalqueiro, I. J. (2007). Cytogenetic characterization of seven South American species of Nereididae (Annelida: Polychaeta): Implications for the karyotypic evolution. Journal of Basic \& Applied Genetics, 18, 27-38.

Klesch, W. L. (1970). The reproductive biology and larval development of Laeonereis culveri Webster (Polychaeta: Nereididae). Contributions in Marine Science, University of Texas, 15, 71-85.

Liñero-Arana, I., \& Díaz-Díaz, O. (2007). Nuevas adiciones de Nereididae (Annelida: Polychaeta) para las costas de Venezuela. Boletín del Instituto Oceanográfico de Venezuela, 46, 149-159.
Mazurkiewicz, M. (1975). Larval development and habits of Laeonereis culveri (Webster) (Polychaeta: Nereididae). Biological Bulletin, 149, 186-204.

Mazurkiewicz, M. (2009). The ontogeny of parapodia and setae in Laeonereis culveri (Webster) (Polychaeta: Nereididae). Zoosymposia, 2, 369-377.

Monro, C. C. A. (1937). On some freshwater polychaetes from Uruguay. Annals and Magazine of Natural History, Series 10, 20, 241-250.

Oliveira, V. M., Santos, C. S. G., Lana, P. C., \& Camargo, M. G. (2010). Morphological variations caused by fixation techniques may lead to taxonomic confusion in Laeonereis (Polychaeta: Nereididae). Zoologia, 27, 146-150.

Omena, E. P., \& Amaral, A. C. Z. (2001). Morphometric study of the nereidid Laeonereis acuta (Annelida: Polychaeta). Journal of the Marine Biological Association of the United Kingdom, 81, 423-426.

Orensanz, J. M., \& Estivariz, M. C. (1971). Los anélidos poliquetos de aguas salobres de la provincia de Buenos Aires. Revista del Museo de La Plata (nueva serie). Zoología, 11, 95-104.

Orensanz, J. M., \& Gianuca, N. M. (1974). Contribuiçao ao conhecimmento dos anelídeos poliquetas do Rio Grande do Sul, Brasil, 1. Lista sistematica preliminar e descrição de trois novas espécies. Comunicaciones du Museo de Ciencias, Pontificia Universidade Rio Grande do Sul, 4, 1-37.

Pamplin, P. A. Z., de Almeida, T. C. M., \& da Silva-Filho, J. P. (2007). New record of Laeonereis acuta (Treadwell, 1923) (Nereididae: Polychaeta) in Northeast coast of Brazil. Biota Neotropica, 7, 353-355.

Pettibone, M. H. (1971). Revision of some species referred to Leptonereis, Nicon, and Laeonereis (Polychaeta: Nereididae). Smithsonian Contributions to Zoology, $104,1-53$.

Read, G. (2015). Laeonereis. In G. Read, K. Fauchald (Eds.), World Polychaeta database. Retrieved from http://marinespecies.org/aphia. php? $=$ taxdetails \&id $=181592$

Read, G., \& Glasby, C. (2015). Nereididae Blainville, 1818. In G. Read, K. Fauchald (Eds.), World Polychaeta database. Retrieved from http://www. marinespecies.org/aphia.php? $\mathrm{p}=$ taxdetails\&id=22496

Reish, D. J. (1957). The life history of the polychaetous annelid Neanthes caudata (delle Chiaje), including a summary of development in the family Nereidae. Pacific Science, 11, 216-228.

Salazar-Vallejo, S. I., Carrera-Parra, L. F., González, N. E., \& Salazar-González, S. A. (2014). Biota portuaria y taxonomía. In A. M. Low-Pfeng, P. A. Quijón, \& E. M. Peters-Recagno (Eds.), Especies Invasoras Acuáticas: Casos de Estudio en Ecosistemas de México (pp. 33-54). México: SEMARNAT, INECC \& Univ. 
Prince Edward Island. Recuperado de http://www2. inecc.gob.mx/publicaciones/consultaPublicacion. html?id_pub=713)

Salazar-Vallejo, S. I., \& Jiménez-Cueto, M. S. (1997). Neréididos (Polychaeta) del Caribe mexicano con una clave para las especies del Gran Caribe. Revista de Biología Tropical, 44, 361-377.

Santos, C. S. G., Pleijel, F., Lana, P., \& Rouse, G. W. (2005). Phylogenetic relationships within Nereididae (Annelida: Phyllodocida). Invertebrate Systematics, 19, 557-576.

Simonis, J. L., \& Ellis, J. C. (2014). Bathing birds bias beta-diversity: frequent dispersal by gulls homogenizes fauna in a rock-pool metacommunity. Ecology, 95, 1545-55.

Treadwell, A. L. (1923). Two new species of polychaetous annelids of the genus Nereis from Brazil. Revista do Museo Paulista, 13, 1-10.
Treadwell, A. L. (1941). New species of polychaeous annelids from the vicinity of Galveston, Texas. American Museum Novitates, 1139, 1-3.

Weber, L. M., \& Haig, S. M. (1997). Shorebird diet and size selection of nereid polychaetes in South Carolina coastal diked wetlands. Journal of Field Ornithology, 68, 358-366.

Webster, H. E. (1879). Annelida Chaetopoda of New Jersey (Annual Report No. 32, 1878). New York: New York State Museum of Natural History.

Withers, K. (2002). Shorebird use of coastal wetland and barrier island habitat in the Gulf of Mexico. Scientific World Journal, 2, 514-536.

Withers, K., \& Chapman, B. R. (1993). Seasonal abundance and habitat use of shorebirds on an Oso Bay mudflat, Corpus Christi, Texas. Journal of Field Ornithology, 64, 382-392. 
